\title{
Russian Comic Opera in the Age of Catherine the Great ${ }^{1}$
}

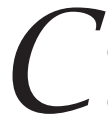

omic opera was introduced in Russia in the early 1770s. It remained one of the country's favorite dramatic forms until the end of that century. The term "comic opera" may perhaps be misleading in this case. We are not talking of La serva padrona or Le nozze di Figaro or of any other eighteenth-century comic opera that requires opera singers to perform. Russian comic opera of the age of Catherine was essentially a literary rather than a musical-dramatic genre. It was a brief (one- or twoact) play that included songs, vocal ensembles, and occasionally choruses. The performers were actors with some singing ability rather than trained singers. The music for these productions was at times composed by Russian or resident foreign composers, but equally often there would be no original musical score, the performers being instructed to sing their vocal numbers to the tune of this or that popular air of the day.

In its native France, this form of music drama had a more appropriate name: comédie mêlée d'ariettes. Its main practitioner was Charles-Simon Favart (1710-92). During his four decades of writing musical comedies, Favart bridged the transition from the comédie en vaudevilles, associated with the theatricals at the two annual Paris fairs (théatre de foire, in which Favart did his playwriting apprenticeship in the 1730s), to the true French opéra-comique at the end of the century. Favart's comedies treated a variety of themes and social situations, but some of his most lasting successes depicted peasant life in the countryside. The plot invariably showed two young peasant lovers overcoming obstacles to their union, be it parental opposition or interference by a villainous bailiff. A favorite plot device was to involve a naive, inexperienced peasant girl with a man above her on the social scale and in a position to hold her in his power. This was the situa-

1 Originally published in 19th-Century Music 7 (April 1984):318-25, and subsequently as part of ch. 5 of Russian Drama from Its Beginnings to the Age of Pushkin, by Simon Karlinsky (Berkeley: University of California Press, 1985). 
tion in Favart's Le caprice amoureux, ou Ninette à la cour (1755), Annette et Lubin (1762) and Les moissonneurs (The reapers, 1768), the last being a musical comedy version of the Book of Ruth in the Bible.

Favart's manner of presenting peasant life on the stage has been compared to the idealized and bucolic canvases of Boucher and Watteau. Because of his enormous popularity, these plays were soon exported to other countries and adapted to local tastes and conditions. ${ }^{2}$ Thus Ninette $\dot{a}$ la cour reappeared in Germany as Lottchen am Hofe, in England as Phoebe at Court, in Italy as La contadina in corte, and in Sweden as Lantflickan på hovet. In 1783, it was incarnated as La villanella rapita, a comic opera with libretto by Giovanni Bertati and music by Francesco Bianchi, with two additional scenes composed by Mozart (K. 479 and 480) for the 1785 production in Vienna. Similar transformations occurred with other successes of Favart, leading to a great vogue for rustic settings and for peasant girl-peasant boy-nobleman (or bailiff) triangles in comedy and comic opera throughout the Western world.

By the time Lorenzo Da Ponte used this theme in his libretti for Mozart's Le nozze di Figaro (the Susanna, Figaro and the Count imbroglio) and Don Giovanni (Zerlina, Masetto and the Don), in 1786 and 1787, respectively, he was offering his own version of possibly the most widespread comedic plot situation of the century. The famous Don Giovanni-Zerlina duet "Là ci darem la mano" is a rare living survivor of the hundreds upon hundreds of duets of similar content and tone that resounded for half a century in every theater in Europe.

Another work whose international success helped enhance the fashion for paysannerie in musical comedies was Jean-Jacques Rousseau's Le devin $d u$ village, premiered in Paris in 1752. Considered the first genuine French comic opera (in that, unlike the earlier comédies d'ariettes, it was provided with a musical score of its own), Rousseau's brief idyll about a peasant couple brought together by a kindly quack consolidated the custom of letting the musical theater voice a preference for the wholesome rustic life over the supposedly corrupt life of the cities. Le devin $d u$ village became the object of innumerable imitations, one of the most

2 On the impact of Favart on the whole of Europe (with the exception of the Slavic countries), see Alfred Iacuzzi, The European Vogue of Favart (New York: Institute of French Studies, 1932). 
popular of which was Favart's parody of Rousseau, Les amours de Bastien et Bastienne (1753), also widely copied and imitated. Its progeny included the brief opera Bastien und Bastienne, composed by the twelve-year-old Mozart for a performance at the home of Dr. Anton Mesmer, the originator of the notion of animal magnetism.

A third French name essential for tracing the origins of the comic opera in Russia is Michel-Jean Sedaine (1719-97), author of comic-opera libretti for such popular composers of the second half of the eighteenth century as Philidor, Pierre Monsigny, Egidio Duni, and André Grétry. A follower and personal disciple of Denis Diderot, Sedaine obeyed in the libretti of his earlier period Diderot's behest that theater deal with all occupations and social classes. Thus the protagonists of Sedaine's Blaise le savetier (1759, music by Philidor) are a poor village cobbler and his wife; in Le jardinier et son seigneur (1761, also with Philidor), a kitchen gardener is humiliated and his wife and daughter are insulted during a visit from an inconsiderate noble and his entourage; and in Le roi et le fermier (1762, music by Monsigny), King Henri IV of France finds refuge in the hut of a peasant whose fiancée has been abducted by neighboring nobles.

Sedaine's most popular comic opera, Le déserteur (1769, also with Monsigny), deals with the adventures of a simple army private who gets into trouble because of a practical joke played on him by his future fatherin-law. Through their great currency, these early libretti of Sedaine (his later ones, including the one for Grétry's Richard Cour de Lion, 1784, dealt mostly with royalty) greatly expanded the social purview of comic opera. ${ }^{3}$ Between them, Favart, Rousseau, Sedaine, and a host of their contemporaries and imitators made the poorer and humbler classes the expected and accepted protagonists in comic opera. Servants, peasants, artisans, or gardeners who could appear in subsidiary or episodic roles in neoclassical comedy and sentimental drama were now shown to have love lives of their own and interesting and at times paradoxical emotions. Although the surviving conventions of the dramatic pastorale could upon occasion force the rustic protagonists of the new genre into the poses and attitudes of Arcadian shepherds and shepherdesses, the extended social

3 On the significance of Sedaine, see Louise Parkinson Arnoldson, Sedaine et les musiciens de son temps (Paris: Entente Linotypiste, 1934). 
purview of the opéra comique did represent a step in the direction of a more democratic theater.

Russians became acquainted with this new genre during the guest appearances of a French touring company in St. Petersburg in the years 1764-68. ${ }^{4}$ Because of the continuing orientation toward Parisian tastes and the widespread practice of "adaptation to our customs," it was inevitable that Russian comic opera would materialize. The earliest chronologically was Anyuta, a one-act comedy with music, which was performed for Catherine by the members of her church choir at Tsarskoe Selo on 26 August 1772. Anyuta is generally considered the ancestress of all Russian operetta and musical comedy. The text was written by Mikhail Popov (1742-ca. 1790), otherwise known as one of the actors of the Imperial Theaters and as a journalist and folklore collector. The music for

4 R.-Aloys Mooser, L'opéra-comique français en Russie au XVIIIe siècle (Geneva: R. Kister, 1954), 45ff. The same author's Opéras, intermezzos, ballets, cantates, oratorios joués en Russie durant le XVIIIe siècle (Geneva: R. Kister, 1955) is a useful tabulation of foreign and Russian works for musical theater during the period in question.

The utilitarian-minded Russian scholars of the nineteenth and early twentieth centuries had little interest in studying the arts and the culture of the eighteenth century. Modern understanding of the nature of eighteenth-century comic opera begins with Nikolai Findeizen's Ocherki po istorii muzyki v Rossii, 2 vols. (Moscow and Leningrad: Gos. izd-vo Muzsektor, 1928), published posthumously but written, to a large extent, before the Revolution. This work has served as the basis of literary and musicological studies of comic opera that have appeared since its publication. From the 1930s and especially the 1940s on, understanding of Russian eighteenth-century music and literature has been handicapped by the ultranationalistic stance assumed by Soviet culture, which requires that Western sources of Russian art be minimized or altogether ignored.

Recent Soviet studies of Russian comic opera as a literary genre either have ignored its dependence on its French models or have gone to the extent of denying this dependence altogether. Thus, P. N. Berkov, in his often excellent Istoriia russkoi komedii XVIII v. (Leningrad: Nauka, 1977), 180ff., disregards the development of the genre in the West and the productions of representative French comic operas in St. Petersburg throughout the 1760s (of all of which he is aware, since he cites Mooser's studies) and seeks, quite unconvincingly, to derive Russian comic operas from native folklore traditions, such oral folk plays as Tsar Maximilian, and comedies by Russian neoclassical playwrights.

Soviet musicologists offer a somewhat more factual and historically balanced account of the genesis of the genre in Russia; see, for instance, Iu. V. Keldysh, Russkaia muzyka XVIII veka (Moscow: Nauka, 1965), ch. 6. But even they have not ventured a full-dress comparison of the Russian texts with Favart and Sedaine, which is the crux of the matter. 
this piece is lost. It is not clear whether there was an original score composed for it or whether, as was often the practice with Favart, the musical numbers were simply sung to the melodies of currently popular songs (known as timbres in France).

Popov's play follows closely the mode of representing peasant life developed by Favart and Rousseau. The heroine, the adopted daughter of a poor peasant, is being forced into a distasteful marriage with a hired hand. A handsome young nobleman named Viktor falls in love with her and, upon investigating her origins, discovers that Anyuta is a noblewoman by birth, the daughter of a colonel, and thus a suitable match for himself. The disappointed foster father and the hired hand are easily placated by small sums of money. The concluding ensemble chants the praises of the stratified social system: "Do not try to possess things you were not meant to own.... / He who is pleased with his lot / Is the most fortunate man in the world!" While their extreme poverty and very hard life are made explicit in the play, Anyuta and the two peasant men are shown as crude, grasping, foul-mouthed creatures. Only the noble Viktor is endowed by the author with some semblance of dignity and humanity.

For all its lack of dramatic polish and human insight, Popov's Anyuta did set the pattern for the numerous comic operas that were written and produced in Russia during the following three decades. Popov's incorporation of native folk song texts into his play led his followers to feature such songs, either authentic or imitation, in their plays. The name Anyuta (probably inspired by Favart's Annette et Lubin, known as Anyuta i Lyubim in Russian and widely performed in the 1760s and 1770s both in versions set in France and in "adaptations for our customs") became as canonical for peasant heroines in comic opera as Sofiya was for young gentlewomen in serious comedy.

In the wake of successful productions of imported comic operas with texts by Favart and Sedaine and of Anyuta, Russian playwrights and poets took to writing comedies with music that reflected, with greater or lesser fidelity, the situation of the humbler classes of the time: peasants (both enserfed and free), artisans, lower ranks in the army and the navy, and, eventually, the merchant class and even the clergy. The comic opera was thus the dramatic genre that encompassed a social range broader than any other of its time. 
A basic fact of Russian lower-class life of the time was the form of slavery known as serfdom. For all of her enlightenment and oft-reiterated opposition to tyranny, Catherine not only supported this archaic institution, but even extended it to areas where it did not previously exist, such as the Ukraine. When the popular successes by Favart that portrayed free peasant farmers in France were transplanted in Catherine's Russia, the result was the first full-scale portrayals on the Russian stage of serfs as protagonists. Now, criticism of mistreatment of serfs by their owners and of other abuses of serfdom was permitted and expected in that age to a degree that would seem unbelievable in the early nineteenth century. But it was permitted only provided that the abuses were attacked, not the institution itself. Catherine herself offered an example of such permissible criticism in her comedy What Tricks Are These?

Therefore no eyebrows were raised when Nikolai Nikolev (17581815) presented his "drama with voices" Rozana and Lyubim (premiered in Moscow in 1778 and regularly played in both capitals until the end of the century), with music composed by one of the members of the Kertselli (Kerzelli) family, either Ivan or Iosif. It was a comic opera about a peasant maiden, abducted by an amorous nobleman who eventually repents and returns her to her father so that she can marry the young fisherman she loves. Nikolev's libretto was a Russification of two of $\mathrm{Fa}$ vart's greatest successes: Annette et Lubin and Ninette à la cour. He followed these two texts with so much fidelity, in fact, that he anticipated by seven years Bertati's libretto for the Bianchi-Mozart La villanella rapita, which, had it not postdated Nikolev's effort, might have easily been mistaken for its model.

No one in the eighteenth century would have thought Nikolev's text incendiary, nor would the ruling classes (royalty and nobility), the principal audience of comic opera performances, ever have tolerated a work that they thought was directed against themselves or their interests. Both the authors of comic operas and the spectators considered the institution of serfdom a given of Russian life which, like all human institutions, was capable of being abused. In recent decades, however, an ahistorical interpretation of all this has prevailed in the Soviet Union, according to which such works as Rozana and Lyubim were denunciations of serfdom based not on Russifications of Favart and his contemporaries, but rather on the playwright's personal observations of concrete social 
realities. ${ }^{5}$ A mechanical binary oppositional system of classifying literary works as progressive or reactionary has forced scholars to classify all eighteenth-century comic operas that depict serfdom as one or the other, depending on whether or not the serf owners are attractively portrayed.

In this manner, Rozana and Lyubim and Yakov Knyazhnin's somewhat more original Misfortune from a Coach $^{6}$ have become standard exhibits in Soviet textbooks, representing enlightened opposition to the upper classes and to slavery. Conversely, The Village Feast, or Virtue Crowned (Derevenskii prazdnik, ili Uvenchannaia dobrodetel', 1777) by the poet Vasily Maikov (1728-78), with music by Mikhail Kertselli, has at times been assaulted as a reactionary, proserfdom tract, merely because it shows the relations between the serf owner and his serfs as amiable. ${ }^{7}$ One could

5 Berkov's Istoriia russkoi komedii XVIII $v$. is unique among the Soviet literary and musicological studies of the last three decades in denying that Nikolev's Rozana and Lyubim and similar works from its period (such as Knyazhnin's Misfortune from a Coach [see n. 6 below]) are antiserfdom tracts (190ff., 207ff.).

6 The playwright Yakov Knyazhnin (1742-91) is invariably remembered in posterity by the merciless epithet which Pushkin applied to him in Evgeny Onegin: pereimchivyi [imitational]. His neoclassical tragedies, much appreciated by his contemporaries, were transpositions into medieval Russia of the successful Italian (Pietro Metastasio, Scipione Maffei) or French (Racine, Voltaire) works of that genre. His lively verse comedies were a landmark in the development of Russian literary language.

It is Knyazhnin's comic operas, however, that Pushkin's epithet most obviously fits. His two great successes in this genre were Misfortune from a Coach (Neschast'e ot karety, 1779; this title is often translated as Accident with a Carriage by commentators who are not familiar with the plot), with music by Vasily Pashkevich, and The HotMead Vendor (Sbitenshchik, 1784), with a score composed by the Czech bassoonist Anton Bullandt. The first of these operas combines typical Favart features with some pointed commentary on the heartless custom of Russian noblemen selling their serfs into military service as a way of raising money for luxuries, in this case for an imported French coach. The Hot-Mead Vendor is a clever splicing together of characters and plots from well-known comedies by Molière, Sedaine, and Beaumarchais. The popularity of Knyazhnin's comic operas was second only to that of the Ablesimov and Matinsky works discussed here. Both Misfortune from a Coach and The Hot-Mead Vendor remained in the repertoire of Russian theater until the 1820s.

7 For example, B. N. Aseev, Russkii dramaticheskii teatr XVII-XVIII vekov (Moscow: Iskusstvo, 1958), 315 ("a typical example of a reactionary comic opera"; in the revised edition of the book, Russkii dramaticheskii teatr ot ego istokov do kontsa XVIII veka (Moscow: Iskusstvo, 1977), the adjective "reactionary" was changed to "pseudopopular"); and Keldysh, 259 ("a reactionary feudal idyll"). Because of this reputation, The Village Feast has been excluded from the collections of Maikov's poetry and plays that have appeared in postrevolutionary times. It can be found in Sochineniia i perevody V. I. Maikova, ed. L. N. Maikov (St. Petersburg: P. A. Efremov, 1867). 
as easily turn this around and show that Maikov's portrayal of serfdom is far grimmer than Nikolev's.

Styled as "a pastoral drama with music in two acts," Maikov's play begins with the mannered wooing of a coy shepherdess by an eloquent shepherd. They seem to have stepped right off a delicate Sèvres teacup. These Rococo porcelain creatures are intended to represent Russian serfs living in the environs of Moscow. In the second act the lovers are duly betrothed, with the kindly aid of their owner. Other assembled serfs chant the praises of their wise master. An ideal relationship thus seems to exist between serfs and their owners. The benevolent squire expresses his concern for the welfare of his subjects to a visitor and in a vocal solo accompanied by a peasant chorus sings:

If my peasants are pleased with me

Then I am pleased with myself.

If they are wealthy and free,

Therein lies all my joy.

But the chieftain of a transient band of gypsies (who are treated in this play with the kind of racist contempt that late nineteenth-century Russian melodrama reserved for Jews, and Soviet drama of the late 1950s for Americans) gives the squire some sharp arguments. To his preaching of honor and virtue, the gypsy, in a tone reminiscent of Brecht's Threepenny Opera, rejoins with the following sung argument:

He who has something in his pocket

Will be honored even by the Heathen.

But he whose pocket is empty

Will buy nothing with his honor.

He will be indeed vanquished by hunger

And allowed to die among the Christians.

The gypsy's pretended astuteness at reading palms (which helps unite the lovers) so frightens the squire's bailiff that he confesses having instituted a system of bribes in the village, thereby bringing some serfs to the verge of ruin. And even though the virtuous serf owner promises 
to set everything right, the play's most striking point has been made: Maikov's happy peasants, who do not have to contend with the cruel voluptuary of Rozana and Lyubim and are not owned by the irresponsible and silly Gallomaniacs of Knyazhnin's Misfortune from a Coach, are still not protected from oppression and exploitation even though their owner happens to be a benevolent singing philosopher. It can thus be seen that any eighteenth-century comic opera can be used to demonstrate the inhumanity of slavery if one looks at it from the viewpoint of later, more enlightened times.

It is a measure of the freedom of Russian literature from censorship pressure in the reign of Catherine II prior to the French Revolution that the social issues raised by serfdom could be reflected in comic opera as openly as they were. Certainly the more outspoken examples of this genre could not have been published or performed in the reigns of Alexander I or Nicholas I half a century later. Yet in the 1770s and 1780s these works were produced at Catherine's court and in open public theaters and were performed by serf actors in the private theaters of wealthy magnates. Nor is there any indication that the empress and the upper hierarchy felt themselves indicted by the depiction of the abuses of serfdom in comic opera, any more than an American politician or banker today feels himself personally indicted by a portrayal of a corrupt politician or a dishonest banker in a Hollywood film.

The most popular Russian comic opera on a peasant subject, however, ignored serfdom altogether. It owed its huge and lasting success to the charm of its music and to the wit and gaiety of its dialogue, written in authentic-sounding peasant dialect. This was The Miller Who Was a Wizard, a Cheat, and a Matchmaker (Mel'nik-koldun, obmanshchik i svat $)^{8}$ by Aleksandr Ablesimov (1742-83), otherwise known as a minor journalist of the period and the author of several other, forgettable libretti. Initially performed in Moscow in 1779, The Miller had for a musical score

8 This title is usually rendered into English with the four nouns separated by commas (e.g., D. S. Mirsky, A History of Russian Literature [New York: Alfred A. Knopf, 1958], 54). This creates the impression that the title refers to four characters: a miller, a wizard, a cheat, and a matchmaker. In the original Russian, the last three nouns serve as epithets, qualifying the miller. All four nouns refer to the same character. 
a pastiche of Russian folk songs arranged by the violinist and conductor Mikhail Sokolovsky. ${ }^{9}$

One of the numerous progeny that Rousseau's Le devin du village engendered all over Europe (a not unillustrious lineage, since it also includes Mozart's Bastien und Bastienne), ${ }^{10}$ The Miller shows the unlikely predicament of a free peasant who is married to an impoverished noblewoman, and of their daughter, named of course Anyuta, who is in love with a neighboring farmer. Each of the parents wishes the daughter to marry into his or her own social class. The miller of the village, who moonlights as a quack magician, helps the young couple by convincing the parents that the young man is fatally predestined to be Anyuta's husband. The miller placates the parents' social prejudices with the argument that an independent farmer who owns his own homestead (odnodvorets) is a peasant and a nobleman at the same time.

The racy arguments among the characters and the abundance of popular peasant songs (including some that were taken from the traditional wedding ritual), plus such novelties as having a live horse onstage and real Russian balalaikas in the orchestra, all added up to an overwhelmingly

9 SK's original text included the then widely accepted information that Sokolovsky's score was "later revised by the composer Evstignei Fomin." Although the Dramaticheskii slovar', a dictionary of drama published in Moscow in 1787, informed its readers that the score of The Miller "was arranged from old-Russian [russkie] songs by the contemporary Russian [rossiiskii] musician of the Moscow theater, Mr. Sokolovsky," his name did not appear either in the original printed libretto (Moscow, 1782) or in any surviving performance material; the music was attributed on account of its quality to Fomin, the most accomplished dramatic composer of the period, and first published under his name (vocal score, Moscow: Jurgenson, 1884). For a full clarification, see Aleksei Vasil'evich Finagin, "Evstignei Fomin: zhizn' i tvorchestvo," in A. V. Finagin et al., Muzyka i muzykal'nyi byt staroi Rossii: materialy i issledovaniia (Leningrad: Academia, 1927), 94-5.-Ed.

10 This obvious dependence of Ablesimov on Rousseau, recognized by prerevolutionary commentators and by Nikolai Findeizen (Ocherki po istorii muzyki, 2:213 and 216), has been either flatly denied in recent Soviet scholarship (Keldysh, 287-88), or else challenged. B. N. Aseev, Russkii dramaticheskii teatr ot ego istokov do kontsa XVIII veka (Moscow: Iskusstvo, 1977), 425-26, admits the similarities between Rousseau and Ablesimov, but denies that Ablesimov imitated his French predecessor: "The contrast between the natural and pure country life and the corrupting influence of the city, which is present in Rousseau's opera, is replaced in Ablesimov's play with the contrast between peasants and noblemen and, most importantly, with glorification of free peasant labor." 
successful work. The Miller brought about a host of imitations, spread the renown of the genre of comic opera throughout Russia, and became a favorite for amateur theatricals (Vissarion Belinsky, the future critic, played the part of the father in an amateur student production in the late 1820s). It retained its popularity well into the nineteenth century and was occasionally revived in Soviet times.

The only other eighteenth-century Russian comic opera to enjoy a success comparable to The Miller was The St. Petersburg Bazaar (Sanktpeterburgskii gostinyi dvor) ${ }^{11}$ by Mikhail Matinsky (1750-ca.1820). Matinsky was born a serf, possibly an illegitimate son of his owner. Aware of his intelligence and talents, the owner sent him to study in Italy (in this he followed a widespread custom during Catherine's reign; some of the best Russian painters and musicians of the period were Italian-schooled emancipated serfs). Upon returning to Russia, Matinsky was given his freedom and became a teacher of mathematics and geography at the exclusive boarding school for the daughters of the highest nobility, the Smolny Institute. His later writing efforts were devoted to textbooks on geography and geometry. It was during his stay in Italy that Matinsky wrote what is certainly the most original Russian comic opera of the eighteenth century. Matinsky was thought to have also composed the music for this piece. More recent research casts doubts on the assumption that Matinsky ever composed any music at all. ${ }^{12}$

The St. Petersburg Bazaar seems to owe less to a recognizable foreign model than does any other work of this genre. There is no young peasant heroine and, in fact, no love story at all. Matinsky turned his attention instead to the "dark kingdom" of the tradition-bound Russian merchant class. In so doing, he discovered an entirely new social and dra-

11 This work exists in two versions. The second version, revised by Matinsky and with its music rearranged by the court composer Vasily Pashkevich, was performed in 1792 under the title You Shall Be Known by the Way You Live (Kak pozhivesh', tak i proslyvesh'). The first version of the text remained the better known one, but the musical contributions of Pashkevich were incorporated into it in subsequent performances. The first version (i.e., The St. Petersburg Bazaar) is also the one found in various recent collections of eighteenth-century drama, for example the Berkov anthology and (in excerpts) in Khrestomatiia po russkoi literature XVIII veka, ed. A. V. Kokorev (Moscow: Gos. uchebno-pedagogicheskoe izd-vo, 1961). On the differences between the two versions of the play, see Findeizen, 2:224-30, and Keldysh, 315-24.

12 See Keldysh for a summary of this research. 
matic dimension that nineteenth-century Russian drama was to explore and populate. The central character is the wealthy but miserly merchant Skvalygin (Mr. Tightwad), a greedy and unprincipled moneylender, who is shown both in his family life, with his doting, alcoholic wife and his stupid daughter, and in his various business practices.

Skvalygin forms an alliance with his prospective son-in-law, an equally corrupt civil servant named Kryuchkodei (Mr. Hook-and-Crook), who makes a practice of involving transient out-of-town peasants in horse-cart accidents and then extorting money from them for imaginary damages. Skvalygin and Kryuchkodei cook up a complicated financial swindle designed to victimize an army officer and two society ladies who had been careless about getting their dealings with Skvalygin certified and documented. In the second act, the victims invade Skvalygin's home during the engagement party (posidelki) for his daughter and Kryuchkodei, but can obtain no satisfaction. Owing to a clumsy blunder of the daughter, the two crooks believe themselves mutually betrayed and their misdeeds are exposed in the end.

From the very first two scenes, one showing Skvalygin putting the squeeze on the other merchants in the bazaar arcade and the other bringing in the two subsequently victimized noblewomen to bargain in a vocal sextet with four of the merchants, Matinsky displays a truly admirable grasp of the milieu and a profusion of dramatic invention. One original scene follows another throughout: the bargaining of the crafty merchants with their capricious customers; the indignant aria (in the northern tsokanie dialect) of the peasant ${ }^{13}$ forced to pay damages for the accident he knows was caused on purpose; Skvalygin's stingy dispositions for the engagement party refreshments, clashing with the hospitable inclinations of his wife; the carousing of the previously prim and sedate merchants' wives who are briefly left alone with the liquor supply; and the complex and ingenious plot stratagem that brings the villains to justice.

All these scenes achieve a genuine dramatic impact. None of them seems to have any precedent in foreign or Russian comic traditions. Ma-

13 I.e., a dialect in which words containing the sound denoted by the Russian letter $\mathrm{\varphi}$, pronounced "ch," are modified by substitution of ц, pronounced "ts": thus tselovek for chelovek [person].-Ed. 
tinsky managed to make even the moralizing scene between Skvalygin and his remonstrating virtuous nephew (an enlightened young merchant given to charitable works) interesting, lively, and believable. Musically, the work is also one of the finest of its kind, with very successful female choruses in the engagement party scene, pointing the way for future treatment of similar material by Glinka, Chaikovsky, and even Stravinsky (there are phrases in the betrothal scenes of both The Miller and The St. Petersburg Bazaar that have their exact counterparts in the text of The Wedding). Matinsky's use of an urban middle-class dialect for literary purposes was a pioneering event, leading in a direct line, via the merchant-class plays of Pyotr Plavilshchikov and Aleksandr Shakhovskoi, to Gogol's comedy Marriage and the plays of Aleksandr Ostrovsky.

The tendency of comic opera to depict a wide range of social groups led Russian playwrights of the period down some unusual paths. The prolific neoclassical poet and playwright Mikhail Kheraskov (17331807) tried his hand at comic opera with The Good Soldiers (Dobrye soldaty, 1780). The result was closer to sentimental drama than to comic opera. The heroine of the work is unjustly accused of theft while wandering about like Micaëla in search of her missing soldier-lover. There are a phenomenal number of scenes in which people find their long-lost relatives. The novelty of the piece was in its regimental milieu, for which the music by Hermann Raupach (the same composer who had, back in 1758, turned Aleksandr Sumarokov's Alcestis into one of the earliest Russian opere serie) provided an appropriately military background, with bugle calls and sung marches. One of these marches, "We Love You from the Heart" ("My vas liubim serdechno"), entered folklore; it became a favorite song of Russian soldiers in the nineteenth century and was still popular as late as World War I. The Russian equivalent of "For He's a Jolly Good Fellow," it was cited as such in a highly ironical context in Gogol's comedy The Gamblers (1842), where it is sung in honor of a stooge who is helping a band of confidence men swindle the protagonist out of his fortune.

Nikolai Lvov (1751-1803), a good minor poet of the period, an art critic, and a collector of folk songs (he collaborated in the famous LvovPratsch collection of 1790), was responsible for Postal Coachmen at the Relay (Iamshchiki na podstave, 1788). It utilized the traditional musical 
lore of the drivers who transported travelers across the vast Russian plains and whose singing was to inspire so many of the later Russian poets, from Pushkin to Annensky. The musical score for this work, composed by Evstignei Fomin, is one of the most successful and attractive in the entire range of Russian comic opera.

An unexpected turn was taken by comic opera with the production of The Candidate Priest (Stavlennik), first performed by divinity students in the city of Yaroslavl, the "cradle of Russian theater," in 1780. The text was written by Yakov Sokolov, of whom nothing is known except that he was "a student of philosophy." Nor is anything known about the music, for the score has been lost. With The Candidate Priest comic opera invaded the realm of the Russian clergy, who were a separate caste in prerevolutionary times. The story deals with a competition for a job left vacant by the death of the parish priest. The leading candidate is Foma (Thomas), son of a wealthy priest, whose main qualifications for the job are a sonorous, low-pitched voice and a large supply of money his father has provided for bribes.

Other characters in the all-male cast are Foma's rival for the job, the poor bell-ringer's bright son Provor (an invented name, conveying the idea of agility and adroitness), whose family home has burned down and who needs the job desperately, but lacks funds for bribes; a nobleman at whose house Foma is a lodger and who fawns on and flatters the priest's son, his social inferior, so long as the latter provides the liquor; the mercenary secretary of the local administration; the incorruptible city official who has to judge at the candidates' competition; and a comical peasant who disrupts the examination scene when he mistakes Foma's voice for the lowing of his lost cow. The clumsy web of intrigue woven by Foma comes to naught when the well-prepared Provor bests him at reading and singing, but in defeat, Foma puts up a spirited defense for the right of the untalented and the unlearned to fend for themselves by whatever means they can.

Unlike other comic operas of the time that had prose dialogue between the sung numbers, The Candidate Priest follows the example of Popov's Anyuta in having its dialogue in iambic hexameter throughout. The writing is lively and witty, the characterization vivid, and the versification expertly done. There is no record of this work's performance in either 
of the capitals, but it did enjoy a lasting and deserved provincial success. There exists an account of an open-air performance of this piece staged in 1814 to celebrate Napoleon's defeat. Handwritten copies of the text were still circulated in Yaroslavl in the 1830s. What makes this work particularly interesting is its portrayal of members of an important social class that traditionally remained outside the scope of Russian literature until the late nineteenth century, when Nikolai Pomyalovsky, Nikolai Leskov, and Chekhov made the members of the clerical class the protagonists of some of their finer stories and novels. ${ }^{14}$

Before the eighteenth century was over, some 150 Russian comic operas had been written and performed. The popularity of this genre had its impact on the relaxation of the three classical unities, on the acceptance of Russian folk song as raw material for Western-style musical composition (a practice that became even more popular in the nineteenth and twentieth centuries), and on the mode of representing peasants and merchants on the Russian stage by later playwrights. Modern understanding of the historical importance of this genre began with Nikolai Findeizen's pioneering study published in 1928. But some of the more recent Soviet scholarship on comic opera, by saddling the form with anachronistic ideological content and ignoring its Western sources and parallels, has produced as much obfuscation as understanding. ${ }^{15}$

14 The text of The Candidate Priest was published in Russkaia starina (St. Petersburg), June 1875, 277-300. The work was discussed in prerevolutionary histories of Russian drama. In Soviet times, because of its nonsatirical portrayal of clergy, it has usually been relegated to an occasional footnote; in fact, it was hardly mentioned at all until Berkov ventured a brief discussion of it in his Istoriia russkoi komedii XVIII v., 208-11.

15 This comment is not meant to minimize the useful information on Russian eighteenth-century comic opera that is to be found in the work of such literary historians as P. N. Berkov. Two musicological works dating from the ultrarepressive Zhdanov period offer a wealth of valuable documentation through the haze of their compulsory Stalinist clichés and falsifications: A. S. Rabinovich, Russkaia opera do Glinki (Moscow: Muzgiz, 1948), and T. Livanova, Russkaia muzykal'naia kul'tura XVIII veka, 2 vols. (Moscow: Muzgiz, 1953). A good presentation of the musical aspects of the topic in English is to be found in Gerald R. Seaman, History of Russian Music (New York and Washington: Praeger, 1967), vol. 1. The reader should be warned against the uninformed and factually unreliable treatment of Russian comic opera in Richard Anthony Leonard, A History of Russian Music (New York: Macmillan, 1957). James Bakst, in A History of Russian-Soviet Music (New York: Dodd, Mead, 1966), gives the subject an even more ideologically distorted and Stalinist slant than the official Soviet scholars. 
On its original appearance this essay bore a prefatory note, stating: "This paper is based on the materials of my book in progress, Russian Drama from Its Beginnings to the Age of Pushkin. I am particularly grateful to Daniel Heartz and Marie-Hélène Huet for discussing eighteenth-century comic opera with me and for sharing their insights and expertise." The two informants named were distinguished colleagues on the faculty of the University of California, Berkeley (Prof. Huet then on the point of being abducted, in the spirit of comic opera, to Amherst College), in the departments of music and French, respectively. When the book was issued, this essay became its fifth chapter, augmented by the addition of a couple of sections that, departing from the contents of note 6 in the present version, more closely examined the work of Knyazhnin. The great significance of this essay is adumbrated, but done scant justice, in notes 4 and 15, which suggest the great miasma of misinformation and misinterpretation that had previously surrounded the subject of early Russian comic opera. SK is characteristically eager to expose the Soviet contribution to the mess, but Western accounts, inheriting the Romantic nationalist biases of the nineteenth century, were hardly less muddled, hardly less given to promoting the genre as autochthonous, and hardly less prone to draw a line, not forward to the genre from its French prototype, but backward to it from the nationalistic art of post-Napoleonic Russia, as exemplified in music primarily by the work of Glinka (or rather, by the myth of Glinka) and the moguchaia kuchka, or (as they are known in English) the Mighty Five, thus to prove that folkloric nationalism had always been an essential feature of Russian music. The 1961 Oxford dissertation by Gerald Seaman, "The Influence of Folk-Song on Russian Opera in the Eighteenth Century up to and including the Time of Glinka," one of the very first extended academic studies of Russian music in English, conveys the bias in its very title.

The revolutionary aspect of SK's demonstration that Russian comic opera in the eighteenth century was a French import was its concomitant demonstration that folklore played a role in the early Russian operas comparable to the one it played in the French ones-that is, it was invoked to typify lower-class characters, not to characterize "the nation," or the national essence. Rather than denoting nationality or ethnicity, it connoted class. Just 
as the Romantic nationalism of the nineteenth century, although it found expression in a distinctively Russian sound, was a conceptual import from Germany, so the decorative nationalism (more accurately described as exoticism) of the eighteenth century was a generic import from France. SK spelled all of this out in that lapidary, crystalline style of his, and when one of us (RT) was given the task of supplying the Russian entries in the New Grove Dictionary of Opera (London: Macmillan, 1992), no effort was spared to publicize SK's views in the texts, and call attention to the present article, plus the chapter to which it led, in the bibliographies. Recent histories of opera (e.g., and most particularly, the most recent and best one, Carolyn Abbate and Roger Parker, A History of Opera [New York: Norton, 2012]) testify that Karlinskian thinking has infiltrated the general discourse of musicology. 